URL:https://undocs.org/ru/A/CN.9/WG.IV/WP.120 (дата звернення 01.12.2020).

2. Селезньова О.М. Нормативні дефініції в інформативному праві / О.М. Селезньова / «Правова інформатика». - 2014 - № 1(41) - С. 23-29. (дата звернення 01.12.2020).

3. Кодекс України про адміністративні правопорушення: Закон України від 07.12.1984 р. № 8073-Х. / Законотворчість: база даних / Верховна Рада України URL: https://zakon.rada.gov.ua/laws/show/8073110\#Tеxt (дата звернення 02.12.2020).

4. Баранов О. А. Основи класифікації інформаційного законодавства. / О. А. Баранов // Правова інформатика. - 2006. - С. 25-32. http://ippi.org.ua/sites/default/files/06bokiz.pdf C-25-32 (дата звернення 01.12.2020).

5. Про Єдиний державний демографічний реєстр та документи, що підтверджують громадянство України, посвідчують особу чи іiі спеціальний статус: Закон України від 20.11.2012 р. № 5492-VI. / Законотворчість: база даних / Верховна Рада України URL: https://zakon.rada.gov.ua/laws/show/5492-17\#Text (дата звернення 02.12.2020).

6. Щедровицкий Г.П. Путеводитель по методологии организации, руководства и управления. URL: https://econ.wikireading.ru/47970 (дата звернення 02.12.2020).

DOI https://doi.org/10.30525/978-9934-26-040-7-43

\title{
УПРАВЛІННЯ СИСТЕМОЮ НАДАННЯ БЕЗОПЛАТНОЇ ПРАВОВОЇ ДОПОМОГИ: СУЧАСНИЙ СТАН ОРГАНІЗАЦЇ̈ ТА ПРАВОВОГО ЗАБЕЗПЕЧЕННЯ
}

\author{
Матюхіна Н. П. \\ доктор юридичних наук, професор, \\ професор кафедри адміністративного права \\ Національного юридичного університету імені Ярослава Мудрого \\ м. Харків, Україна
}

Ефективність функціонування системи надання безоплатної правової допомоги (БПД), якість правових послуг значною мірою 
залежить від рівня організації та правового забезпечення управління цією системою. Закон України «Про безоплатну правовому допомогу» від 02.06.2011 p. № 3460 основними суб'єктами управління системою надання БПД визначає Кабінет Міністрів України та Міністерство юстиції України (Мін'юст). Відмітимо, разом з тим, посилення ролі та значення з точки зору управлінського впливу на систему надання БПД Координаційного центру 3 надання правової допомоги. Суттєві повноваження щодо управління системою надання безоплатної первинної правової допомоги (БППД) мають органи місцевого самоврядування.

Більш детально зупинимось на характеристиці повноважень окремих із вищеназваних суб'єктів.

Кабінет Міністрів України відповідно до ст. 20 Закону України «Про Кабінет Міністрів України» від 27.02.2014 № 794-VII забезпечує проведення державної правової політики, створює умови для вільного розвитку і функціонування системи юридичних послуг та правової допомоги населенню, здійснює заходи щодо забезпечення функціонування системи БПД. Ці повноваження відносно системи надання БПД конкретизовано у ст. 27 Закону України «Про безоплатну правову допомогу», згідно з якою Кабмін затверджує порядок і умови проведення конкурсу та вимоги до професійного рівня адвокатів, які залучаються до надання безоплатної вторинної правової допомоги (БВПД), встановлює порядок і умови укладення контрактів/договорів 3 адвокатами, які надають БВПД на постійній або тимчасовій основі, затверджує положення про Координаційний центр з надання правової допомоги та реалізує інші повноваження.

Загальне управління у сфері надання БПП здійснює Міністерство юстиції України» (ст. 28 Закону України «Про безоплатну правову допомогу», Положення про Міністерство юстиції України: затв. постановою Кабміну від 02.07.2014 р. № 228). Зокрема, Мін'юст відповідає за впровадження і функціонування системи БВПД, утворює центри з надання БВПД та затверджує Положення про них, затверджує також стандарти якості надання БПД, Порядок оцінювання адвокатів за результатами конкурсу 3 відбору адвокатів та Порядок ведення Координаційним центром Реєстру адвокатів, які надають БВПД. Крім того, Мін'юст здійснює методичне забезпечення органів виконавчої влади і органів місцевого самоврядування стосовно надання БПД, затверджує Типове положення про установи 3 надання БППД. За результатами конкурсного відбору призначає Директора Координаційного центру з надання правової допомоги, затверджує Положення про 
Наглядову раду Координаційного центру, порядок проведення конкурсу щодо обрання ії членів тощо.

Повноваження щодо загального управління у сфері надання БПД Мін'юст здійснює за участю Координаційного центру 3 надання правової допомоги (Координаційний центр), який $\epsilon$ державною установою і належить до сфери управління Мін'юсту. Положення про Координаційний центр затверджено постановою Кабінету Міністрів України від 06.06.2012 р. № 504.

Відповідно до Положення Координаційний центр утворений 3 метою формування та забезпечення функціонування в Україні ефективної системи БПД, забезпечення іiі доступності та якості. Для досягнення цієї мети Координаційний центр здійснює організаційне, експертно-аналітичне, інформаційне та матеріально-технічне забезпечення реалізації повноважень Мін'юсту у сфері надання БПД, вносить на розгляд Міністра юстиції пропозиції щодо формування та реалізації державної політики у зазначеній сфері, здійснює управління системою БВПД, координує діяльність спеціалізованих установ 3 надання БППД, формує Реєстр адвокатів, які надають БВПД, забезпечує проведення моніторингу якості надання адвокатами БВПД та доступності БВПД і відповідно приймає рішення про виключення адвокатів з Реєстру адвокатів, які надають БВПД, контролює діяльність центрів з надання БВПД, а також здійснює інші покладенні на нього повноваження.

Координаційний центр очолює директор, який призначається на посаду і звільняється 3 посади Міністром юстиції за рекомендаціями Наглядової ради щодо кандидатів, які отримали три найвищі конкурсні бали за результатами проведеного конкурсу та інформація стосовно яких передана їй комісією 3 відбору кандидатів на посаду директора Координаційного центру. Порядок проведення конкурсу на зайняття посади директора Координаційного центру затверджений Наказом Мін'юсту від 10.05.207 № 151/5 (у ред. Наказу Мін’юсту від 06.09.2017 № 2823/5).

Директор Координаційного центру очолює Координаційний центр, здійснює керівництво його діяльністю та системою БВПД, несе персональну відповідальність за виконання покладених на Координаційний центр завдань, визначає пріоритети і стратегічні напрями роботи, затверджує плани діяльності Координаційного центру та його територіальних відділень, представляє Координаційний центр у відносинах 3 органами державної влади, органами місцевого самоврядування, юридичними і фізичними особами, видає обов'язкові до виконання працівниками Координаційного центру та його територіальних відділень накази і доручення, здійснює інші повно- 
важення відповідно до законодавства. Окремі управлінські функції у сфері надання БПД реалізують керівники регіональних та місцевих центрів 3 надання БВПД, які є територіальними відділеннями Координаційного центру (Положення про центри 3 надання БВПД: затв. наказом Мін’юсту від 02.07.2012 р. № 967/5).

Новим етапом функціонування системи БПД та управління цією системою стало утворення Наглядової ради Координаційного центру. Це перший такий досвід в Україні. При розробці концепції створення Наглядової ради були враховані напрацювання міжнародної експертної групи. До неї за підтримки Уряду Канади та Офісу Ради Європи в Україні увійшли визнані в світі експерти з питань безоплатної правової допомоги.

Відповідно до Положення про Координаційний центр Мін'юст утворює Наглядову раду з метою забезпечення ефективної реалізації державної політики у сфері надання БПД, незалежності та прозорості управління системою надання БПД. Положення про Наглядову раду та Порядок проведення конкурсу щодо обрання ії членів затверджені відповідними наказами Мін'юсту (наказ від 14.08.2019 № 2551/5 та наказ від 14.08.2019 № 2550/5). Згідно існуючих підходів Наглядова рада виконує функції контролю й моніторингу діяльності Координаційного центру та його керівництва, надає директору Координаційного центру консультативну допомогу щодо стратегічних питань діяльності Координаційного центру, оцінює його діяльність шляхом заслуховування щорічного звіту про функціонування системи надання БПД, визнає за результатами такого оцінювання роботу директора Координаційного центру задовільною чи незадовільною, схвалює річні плани та звіти Координаційного центру, пропозиції щодо подальшого розвитку системи надання БПД та інше. Рішення про визнання роботи директора Координаційного центру задовільною чи незадовільною приймається $2 / 3$ голосів від складу Наглядової ради та подається на розгляд Міністру юстиції.

Склад Наглядової Ради затверджується Мін'юстом, іiі членами не можуть бути працівники органів державної влади, Координаційного центру та його територіальних відділень. Члени Наглядової ради виконують свої обов'язки на громадських засадах. Вони повинні мати бездоганну ділову репутацію, мати підтверджений досвід роботи у сфері захисту прав людини, правосуддя та/або підтримки розвитку системи надання БПД (або інший відповідно до вимог), необхідний рівень вищої освіти та визначені компетенції, забезпечуючи таким чином неупередженість, незалежність та професійність діяльності Наглядової ради. 